\title{
ENSAT Stage II Adrenal Cortex Carcinoma
}

National Cancer Institute

\section{Source}

National Cancer Institute. ENSAT Stage II Adrenal Cortex Carcinoma. NCI Thesaurus. Code C104032.

Stage II includes: T2, NO, MO. Tumor greater than $5 \mathrm{~cm}$. The tumor has not invaded surrounding tissues or organs and has not spread to lymph nodes or distant organs or tissues. (ENSAT 7th Ed, 2009) 